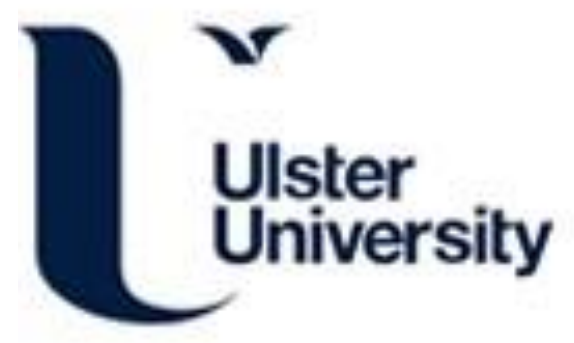

\title{
The Use of Data Collected from mHealth apps to inform Evidence-based Quality Improvement: An Integrative Review
}

Radbron, E., Wilson, V., McCance, T., \& Middleton, R. (Accepted/In press). The Use of Data Collected from mHealth apps to inform Evidence-based Quality Improvement: An Integrative Review: Using data from mHealth apps to inform Evidence-based Quality Improvement. Worldviews on Evidence-Based Nursing , 16(1), 70-77. [WVN-18-079.R2]. https://doi.org/10.1111/wvn.12343

Link to publication record in Ulster University Research Portal

Published in:

Worldviews on Evidence-Based Nursing

Publication Status:

Accepted/In press: 24/09/2018

DOI:

10.1111/wvn. 12343

Document Version

Author Accepted version

\section{General rights}

Copyright for the publications made accessible via Ulster University's Research Portal is retained by the author(s) and / or other copyright owners and it is a condition of accessing these publications that users recognise and abide by the legal requirements associated with these rights.

\section{Take down policy}

The Research Portal is Ulster University's institutional repository that provides access to Ulster's research outputs. Every effort has been made to ensure that content in the Research Portal does not infringe any person's rights, or applicable UK laws. If you discover content in the Research Portal that you believe breaches copyright or violates any law, please contact pure-support@ulster.ac.uk. 


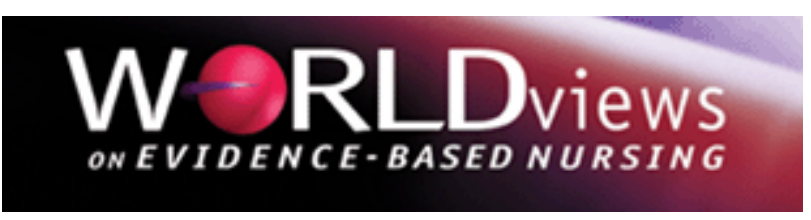

\section{The Use of Data Collected from mHealth apps to inform Evidence-based Quality Improvement: An Integrative Review}

\begin{tabular}{|r|l|}
\hline Journal: & Worldviews on Evidence-Based Nursing \\
\hline Manuscript ID & WVN-18-079.R2 \\
\hline Manuscript Type: & Evidence Review \\
\hline Keywords: & $\begin{array}{l}\text { Quality improvement/Quality of care/Quality of services, Technology, } \\
\text { Primary health care, Nursing Practice, Informatics/Information } \\
\text { technology, Evidence-based practice, Descriptive analysis }\end{array}$ \\
\hline
\end{tabular}

\section{SCHOLARONE \\ Manuscripts}




\author{
Descriptive Title: The Use of Data Collected from mHealth apps to \\ inform Evidence-based Quality Improvement: An Integrative Review.
}

Short title: Using data from mHealth apps to inform Evidence-based

\author{
Quality Improvement
}

\begin{abstract}
Background: The global acceptance and use of technology in healthcare has resulted in an abundance of mobile health (mHealth) applications (apps) available for use in the delivery and improvement of care. With so many apps available to patients and clinicians, it is important to understand how data from apps is being used to inform quality improvement in practice.
\end{abstract}

Aim: The aim of this integrative review is to establish current knowledge of how mHealth apps are used to produce data to inform quality improvement in healthcare.

Method: Scopus, Web of Science, CINAHL and Medline Plus Full Text databases were searched for peer-reviewed papers written in English. The inclusion criteria comprised full text, empirical research studies relating to mobile health application use (not development) in clinical care. 
Results: 19 studies met inclusion criteria. The functions of the apps outlined in the studies can be summarised into four different categories; communication, illness management, clinical management and education/information. The types of data collected by the apps included numerical, textual, photographic, and graphical with several apps able to collect a variety of data types. Analysis of the studies showed that although data collection is rarely outlined as the explicit purpose of mHealth apps, data collected through such technology is and can be used to inform practice change both in real-time and retrospectively.

Linking Evidence to Action: This review highlights while this is an emerging area, data obtained from mHealth apps can and is being used to inform quality improvement in healthcare. Further research is required in this area to adequately understand how data from mHealth apps can be used to produce quality improvement, specifically in relation to nursing. This review also highlights a need for the development of apps that aim to capture data to inform quality improvement, particularly from the patient perspective.

Keywords: mHealth, app, data (or data collection), quality improvement, healthcare, integrative review 


\section{BACKGROUND}

The ubiquitous nature of mobile phones and other portable information technology

(IT) devices has seen the rapid development and acceptance of mobile health

(mHealth) application (app) use in healthcare. The World Health Organisation (WHO)

acknowledge that there is no global consensus on the definition of mHealth and

offer a definition of mHealth as "medical and public health practice supported by

mobile devices, personal digital assistants (PDA's) and other wireless devices" (WHO,

2011 , p. 6). Informed by this definition, this review defines mHealth as 'the use of

mobile technologies to support health information, medical practices and the

achievement of health objectives'.

As a number of definitions of quality improvement in healthcare exist it is essential to also outline how quality improvement is defined in this review. This review draws its definition of quality improvement from the globally recognised Institute for Healthcare Improvement (IHI). The IHI definition/understanding of quality improvement stems from the science of improvement approach. This approach views quality improvement as "an applied science that emphasizes innovation, rapidcycle testing in the field, and spread in order to generate learning about what changes, in which contexts, produce improvements. It is characterized by the combination of expert subject knowledge with improvement methods and tools. It is multidisciplinary - drawing on clinical science, systems theory, psychology, statistics, and other fields" (reprinted from www.IHI.org with permission of the Institute of Healthcare Improvement (IHI), (C2018). This definition of quality 
improvement in healthcare is relevant to healthcare clinicians at all levels of practice from management to clinical care. However, the focus of this article is on those involved in direct clinical care.

In clinical practice, mHealth apps can be used to assist in delivering effective patient care, facilitate research and inform quality improvement by examining data about both illness management and patient experience. Use of mHealth applications in healthcare deliver several benefits over traditional methods by providing convenient, real-time, portable access to health information services and enabling the collection and storage of large amounts of data(World Health Organization (WHO), 2016). Historically, data has been fundamental in supporting and informing change in healthcare. This capacity to support healthcare and collect data results in mHealth apps holding great potential to play a pivotal role in health care delivery and quality improvement.

mHealth apps have been developed to collect and deliver health related information for both patients and clinicians for a variety of purposes including (but not limited to): communication, patient management, medication compliance, diagnostic tools, education, behavioural prompts, reminder purposes, self-management, post-op care, personal health records, and reference information. There are large amounts of evidence available relating to the development and implementation of such apps. However, despite the sizeable number of apps available for both healthcare providers and patients, there is limited evidence available on how the data 
generated from these apps is used, particularly in relation to using that data to inform quality improvement.

\begin{abstract}
AIM
As outlined above, data collected from mHealth apps holds potential to be used to inform sustainable quality improvement in healthcare. As such, the aim of this integrative review is to establish current knowledge of how mHealth apps are used to produce data to inform quality improvement in practice.

\section{METHOD}

This integrative review was performed in accordance with guidelines for integrative reviews by Whittemore \& Knafl (2005) and Hopia, Latvala \& Liimatainen (2016).
\end{abstract}

\title{
Search Strategy
}

In October 2017, a comprehensive search of the Scopus, Web of Science, CINAHL and MEDLINE Plus Full Text databases was performed (see Figure i) to identify current evidence suitable to answer the PICO question 'how are apps used to produce data in healthcare to inform quality improvement?

Key words used in the search strategy included apps OR app OR "mobile application", healthcare OR "healthcare" OR hospital OR nursing OR "quality improvement" OR "quality*" OR "practice improvement". Each search string was combined with the boolean operator AND to obtain focused results. Each search string was searched in both title and topic to ensure comprehensive coverage of the 
topic of interest and was altered to search each database's individual requirements. Full details of the electronic search strategy used in the Web of Science database can be seen in Table 1.

\section{Study Selection and Data Extraction}

One reviewer independently evaluated the search results based on an agreed inclusion criteria of a) full text, b) empirical research studies, c) relating to mobile health application use (not development) d) in clinical care. Excluded from the review were research protocols, manuscripts, editorials, conference papers and nonEnglish publications, apps that provided education/information and didn't collect data, or papers on app development. Data was then extracted from the 19 studies that met the inclusion criteria and collated in an electronic table (Table 2). This process and its results were then critiqued by the other investigators.

\section{Quality Assessment}

To assess the validity of the results and relevance of the studies identified, quality assessment of the articles included in the review was completed using the Critical Appraisal Skills Programme (CASP) checklists for critical appraisal of qualitative research(CASP, 2017), randomised controlled trials (CASP, 2017a) and systematic review (CASP, 2017b). These tools were selected, as they are well-recognised tools in critical appraisal of research and provide a variety of checklists to systematically assess the varying study designs found in the research studies included. Risk of bias within the studies was assessed using The Cochrane Risk of Bias Tool (Higgins et al., 2011). 


\section{RESULTS}

The search strategy yielded a total of 710 articles from across all four databases, which reduced to 634 once duplicate articles were removed. It is important to note that CINAHL and Medline Plus Full Text yielded many results for each individual search string, however when combined with 'AND' nil results were obtained. The 634 articles identified from the database searches were screened by title and abstract and 563 records were excluded based on the inclusion/exclusion criteria (of which a large number were research protocols). The 71 remaining articles identified were then located in full text and reviewed in more depth to assess for eligibility. Further screening of the reference lists of these articles also identified 4 additional articles. After reviewing these articles in relation to the exclusion criteria, a total of 56 articles were excluded and 19 articles were selected for evidence synthesis.

\section{Study Characteristics}

The years of studies yielded in the initial database searches spanned from 19912017. However, the articles that met the inclusion criteria for evidence synthesis spanned from 2012-2017 indicating the emergence and developing nature of this topic in healthcare over the last five years. Studies were conducted in 17 different countries including seven in the United States of America, four in Canada, two in the United Kingdom, Sweden, China and Korea, and one in Turkey, New Zealand, Germany, India, Iran, Japan, Democratic Republic of Congo, Spain, Czech Republic, Italy, and Australia. One study reported by Holmen, Wahl, Smastuen \& Ribu (2017) was conducted across three countries. 
Studies varied greatly in their aims, methodologies and sample sizes. A variety of study designs were selected for analysis, including 4 systematic reviews (Holmen et al., 2017; Kitsiou, Pare, Jaana \& Gerber, 2017; Lee et al., 2015; Peiris, Praveen, Johnson \& Mogulluru, 2014), 4 randomised control trials (Armstrong, Coyte, Brown, Beber \& Semple, 2017; Cingi et al., 2015; Lakshminarayana et al., 2017; Wolf et al., 2016), 1 non-randomised control trial (Sundberg et al., 2017), 3 retrospective cohort studies (Dickson, Sumathipala \& Reeves, 2016; Khanna, Sambandam, Gul \& Mounasamy, 2015; Twichell et al., 2017), 6 pilot studies (Foo et al., 2015; Gunter et al., 2016; Jakel et al., 2016; Macpherson et al., 2014; Patel, Siegler, Stromberg, Ravitz \& Hanson, 2016; Semple, Sharpe, Murnaghan, Theodoropoulos \& Metcalfe 2015) and 1 case report (Gernart et al., 2017).

\section{Populations of Interest}

Eleven out of the nineteen studies reviewed involved patients and medical clinicians and three involved medical clinicians alone (with 3/19 studies not specifying population of interest for the apps). Only two studies involved nursing staff (Jakel et al., 2016; Patel et al., 2016). The aim of the study by Jakel et al (2016) was to examine if use of a Provider Resilience mobile application would improve professional quality of life for a cohort of oncology nurses. This app collected data to evaluate healthcare providers level of compassion fatigue, burnout and compassion satisfaction, however, the results of using the application were not statistically significant. The aim of the study by Patel et al (2016) was to evaluate the impact of using a smartphone-based communication app to improve communication between 
healthcare clinicians including clinical teams, doctors, nurses, social workers, pharmacists and secretaries. The outcome of this study was that nurses and doctors both reported texting on a smart device was more efficient and less disruptive than making phone calls or using pagers with statistical significance of $<0.0001$ in responses relating to efficiency and workflow.

All studies selected involved mHealth apps used in a hospital/clinical care context. The predominant population of interest were patients ( 8 adult and 1 paediatric) with two studies looking at both adult and paediatric patients (Lee et al., 2015;

Macpherson et al., 2014) and three studies not explicitly stating the age of the population impacted by the app (Cingi et al., 2015; Dickson et al., 2016; Lee et al., 2015). Five studies reviewed apps relating to healthcare clinicians including medical, nursing, social work, pharmacists, and clerical staff (Foo et al., 2015; Jakel et al., 2016; Khanna et al., 2015; Lee et al., 2015; Patel et al., 2016).

\section{Functions of Apps}

The functions of the apps outlined in the studies were discussed and themed by the authors until consensus was reached on four different categories ; communication, illness management, clinical management and education/information. Despite the different functions, data from all mHealth apps provided support whether that was relating to the patient experience, decision-making or treatment delivery. See Table 3 for a detailed breakdown of app functions. 


\section{Data Collected Using mHealth Apps}

The types of data collected by the apps included numerical data e.g. numbers, survey scores, vital signs (Cingi et al., 2015; Dickson et al., 2016; Foo et al., 2015;

Gernart et al., 2017; Jakel et al., 2016; Sundberg et al., 2017), textual data e.g. using words, phrases or more in depth descriptions (Cingi et al., 2015; Gernart et al., 2017), photographic data e.g. photos of wounds (Khanna et al., 2015; Semple et al., 2015), graphic data where graphs or scales were generated as a result of patient/physician input or where images were selected by users to express symptoms (Foo et al., 2015), with a number of apps able to collect a variety of data types.

As well as the ability to collect an assortment of data types, the apps reviewed were at times able to collect large amounts of data, for example a study on communication (Patel et al., 2016) reviewed 708, 456 text messages whilst another looked at over 6800 abnormal blood pressure measurements (Twichell et al., 2017). There was also considerable variance in study participants ranging from eight orthopaedic residents in a study about the use of smart phone technology in India (Gunter et al., 2016) to over 1450 in a communication study (Patel et al., 2016).

Data collected through apps was used both in real-time to deliver healthcare, inform healthcare decision-making and create self-awareness (Armstrong et al., 2017; Cingi et al., 2015; Dickson et al., 2016; Foo et al., 2015; Gunter et al., 2016; Jakel et al., 2016; Khanna et al., 2015; Macpherson et al., 2014; Semple et al., 2015; Sundberg et 
al., 2017; Twichell et al., 2017), and retrospectively to inform healthcare management (Gernart et al., 2017; Lakshminarayana et al., 2017; Semple et al., 2015; Wolf et al., 2016), communication strategies (Khanna et al., 2015; Patel et al., 2016)and healthcare delivery changes (Foo et al., 2015).

\section{Quality Improvements as a Result of mHealth App Use}

Whilst not the main focus of the apps, a number of quality improvements and outcomes were reported in the studies reviewed. These included improvements to: clinical outcomes (Cingi et al., 2015), disease control and management (Kitsiou et al., 2017; Lakshminarayana et al., 2017), quality of life (Cingi et al., 2015; Sundberg et al., 2017), time to treatment (Dickson et al., 2016; Twichell et al., 2017), communication (Foo et al., 2015; Khanna et al., 2015; Macpherson et al., 2014), awareness of patient information (Khanna et al., 2015; Lee et al., 2015), symptom burden (Sundberg et al., 2017), emotional functioning (Sundberg et al., 2017), medication adherence (Lakshminarayana et al., 2017), time efficiency (Foo et al., 2015; Khanna et al., 2015; Lee et al., 2015; Patel et al., 2016; Semple et al., 2015), disease management (Holmen et al., 2017), follow up time (Armstrong et al., 2017; Semple et al., 2015) and patient management (Foo et al., 2015; Lakshminarayana et al., 2017). Of the nineteen studies reviewed, only one article (Foo et al., 2015) made explicit links outlining that data collected from the app was used to inform quality improvement. The quality improvements outlined by the other eighteen studies were related directly to using the app itself with some articles indicating the potential for future quality improvement based on study results. 


\section{DISCUSSION}

The findings of this review confirm the global interest and potential international impact of mHealth applications to assist in both the delivery and development of healthcare with seventeen countries being represented in the nineteen studies reviewed. As can be seen from the year of publication of included studies (20122017), the use of mHealth apps to produce data that informs quality improvement is an emerging area in healthcare. This is congruent with the findings from Peiris et al (2014) who found a large number of grey literature outlining studies in progress or randomised control trials with findings yet to be reported. This is further reflected in the findings of this review where twelve out of the fifty-six articles excluded were relating to mHealth app development (see Figure i).

It was interesting to note that only two out of nineteen studies involved nursing staff (of which only one had statistically significant results), compared to fifteen involving medical staff. This finding highlights the limited evidence available and subsequent need for further research relating to data collection through mHealth apps in the discipline of nursing. This finding is congruent with Foo et al.(2015), who outlined that further research focussing on nursing teams in relation to the use of mHealth apps used to track patient journey and clinical task management is key to improving the functionality of current apps. The findings of this review also confirm this as the functions of the apps used by nursing staff in this review were relating to education/information and communication not illness or clinical management. Nurses are an integral part of the healthcare team and play a significant role in the delivery of front line patient care. This proximity to patients places them in a key 
position for collection of data that could be used to inform quality improvement, particularly in relation to clinical or illness management.

As mentioned above, the four types of data collected by the mHealth apps in the articles reviewed included numerical, textual, imaged or graphical data with numerical and textual data being the most common form of data collected. However, whilst data collection was possible from all the apps utilised in the studies, review of these studies revealed that data collection was often not the purpose of the apps themselves. The main functions of the apps were to improve communication, illness and clinical management and provide education/information. Although the purpose of the apps was improvement focussed, it was the data collected by the mHealth apps that informed these changes. The data from these apps was used for a variety of purposes resulting in quality improvement e.g. faster identification of changes in patient condition (Semple et al., 2015; Twichell et al., 2017), improving communication processes (Foo et al., 2015; Khanna et al., 2015; Patel et al., 2016), enhancing understanding of quality of life (Cingi et al., 2015; Lakshminarayana et al., 2017; Sundberg et al., 2017), increasing patient compliance (Cingi et al., 2015; Gernart et al., 2017; Kitsiou et al., 2017; Wolf et al., 2016) and improving access to and satisfaction with healthcare (Dickson et al., 2016; Lakshminarayana et al., 2017).

This review outlines that data is collected through mHealth apps both in real-time and retrospectively, with benefits to both approaches. Benefits of utilising real-time data include (but are not limited to) timely interventions and decision-making 
relating to clinical care and illness management and improved accuracy of information collected. The increasing accessibility and portable nature of mHealth devices enables the data collection process to be more efficient and effective due to shorter time spent collecting and collating data when using a mHealth app. It also provides greater access for patients to be involved in data collection from the convenience of their hospital beds or homes. Having data stored in an app rather than paper, and having it accessible in real time also improves the time taken for clinicians/researchers to access this data and make appropriate data-informed changes to practice. Using an app to collect data in real-time reduces the risk of missing data sets; as it is all stored in a central online, secure space and cannot be misplaced after collection. Collecting and using data from mHealth apps retrospectively also equips clinicians with information on healthcare processes over time, which can be used to inform sustainable healthcare change and provide evidence for both clinicians and patients e.g. reviewing effectiveness of interventions (Khanna et al., 2015; Patel et al., 2016), patient treatment compliance via mHealth app diaries (Gernart et al., 2017; Wolf et al., 2016), understanding quality of life (Cingi et al., 2015; Gernart et al., 2017; Wolf et al., 2016), reviewing time to treatment (Dickson et al., 2016) and using data captured on the app as a memory aid when attending follow up appointments (Lakshminarayana et al., 2017).

The most common focus of data collection related to communication and illness management. Collection of data from the patient perspective in relation to the care experience provides key information on the quality of care and its effect on the patient (McCance, Wilson \& Kornman 2016). This data provides a platform for the 
delivery of person-centred care, identification of gaps in care delivery and quality improvement. However only five out of nineteen studies used mHealth apps to explore the patients experience in healthcare and the impact of illness on quality of life (Cingi et al., 2015; Gernart et al., 2017; Lakshminarayana et al., 2017; Macpherson et al., 2014; Sundberg et al., 2017). These studies predominantly provided data for the medical clinician/s caring for these patients with only two studies mentioning providing this information to nurses. This indicates the need for further research where data collected from $\mathrm{mHealth}$ apps is provided to healthcare clinicians, in particular, nursing staff.

This review highlights that data from mHealth apps is used for the benefit of both patients and clinicians in healthcare. For patients this includes recognition of abnormal results (Semple et al., 2015; Twichell et al., 2017), improved illness management (Cingi et al., 2015; Kitsiou et al., 2017; Lakshminarayana et al., 2017; Peiris et al., 2014; Semple et al., 2015; Wolf et al., 2016), improved accuracy of electronic health records and health data (Lakshminarayana et al., 2017; Wolf et al., 2016), real time communication and feedback (Peiris et al., 2014; Sundberg et al., 2017), faster treatment time (Armstrong et al., 2017; Dickson et al., 2016; Semple et al., 2015), enhanced patient experience (Armstrong et al., 2017; Lakshminarayana et al., 2017; Semple et al., 2015; Sundberg et al., 2017), access to health and health system information (Lakshminarayana et al., 2017; Lee et al., 2015), and selfawareness and education (Holmen et al., 2017; Kitsiou et al., 2017; Lakshminarayana et al., 2017). For healthcare providers (predominantly medical), this includes the improvement of communication between healthcare teams (Foo et al., 2015; 
Khanna et al., 2015), improvement of patient management pathways (Dickson et al., 2016; Foo et al., 2015; Twichell et al., 2017), time and cost efficient healthcare delivery (Gunter et al., 2016; Lee et al., 2015; Semple et al., 2015), greater understanding of patient compliance (Kitsiou et al., 2017; Lakshminarayana et al., 2017; Wolf et al., 2016) and the impact of work and illness on emotional well-being and quality of life (Gernart et al., 2017; Jakel et al., 2016; Lakshminarayana et al., 2017; Macpherson et al., 2014).

Whilst the studies reviewed attributed several benefits from utilising mHealth apps, it was interesting to note that only one study's focus was the collection of data through an mHealth app for the purpose of informing quality improvement (Foo et al., 2015). This indicates that the use of mHealth apps to produce data to inform quality improvement is more of an innate outcome rather than an explicit focus within healthcare, highlighting the need for further research and development in this area.

\section{Limitations}

The limitations of this review include having a single reviewer screen and appraise the articles selected, under guidance from supervisors. While every effort was made to retrieve all relevant articles as a result of a rigorous search strategy, it is acknowledged that this search was undertaken at a point in time in what is a rapidly evolving field.

\section{IMPLICATIONS FOR FUTURE RESEARCH}


This review highlights how data obtained from mHealth apps can and is being used to inform quality improvement in healthcare. The emerging nature of this topic evidenced by the recent studies published and low number of high quality evidence of studies available, indicate that further research is required in this area to adequately understand how data from mHealth apps can and is being used to produce quality improvement, specifically in relation to nursing. This review also highlights a need for the evaluation of data produced by existing mHealth apps and the development of apps that specifically aim to capture data to inform quality improvement, particularly from the patient perspective.

\section{CONCLUSIONS}

In conclusion, this review highlights the emerging nature of using data collected from mHealth apps to inform quality improvement in healthcare. Analysis of the included studies showed that although data collection is rarely outlined as the explicit purpose of mHealth apps, when collected through such technology, is used to inform practice change both in real-time and retrospectively. These improvements include benefits for both patients and clinicians such as improved disease control and management, quality of life, communication and time efficiency.

\section{Acknowledgements}

This research has been conducted with the support of the Australian Government Research Training Program Scholarship.

\section{Funding}


This work was supported by the Australian Federal Government Research Training

Program Scholarship.

\section{LINKING EVIDENCE TO ACTION}

- Data from mHealth apps can be used to inform improvements for both patients and clinicians such as improved disease control and management, quality of life, communication and time efficiency.

- Evaluation and use of data from existing mHealth apps used in practice to inform quality improvement is needed.

- Further research is required to adequately understand how data from mHealth apps can be used to produce quality improvement, specifically in relation to nursing.

- This review also highlights a need for the development of apps that aim to capture data to inform quality improvement, particularly from the patient perspective.

- There is a need for increased publication of high quality evidence relating to data collection through mHealth apps used in nursing, particularly from countries in the Southern Hemisphere. 


\section{References}

Armstrong, K. A., Coyte, P. C., Brown, M., Beber, B., \& Semple, J. L. (2017). Effect of Home Monitoring via Mobile App on the Number of In-Person Visits Following Ambulatory Surgery A Randomized Clinical Trial. JAMA Surgery, 152(7), 622-627. doi:10.1001/jamasurg.2017.0111

Critical Appraisal Skills Programme (CASP), (2017). Qualitative Research Checklist Retrieved from http://docs.wixstatic.com/ugd/dded87_25658615020e427da194a325e7773d 42.pdf

Critical Appraisal Skills Programme (CASP) (2017a). Randomised Controlled Trials Checklist Retrieved from http://docs.wixstatic.com/ugd/dded87_4239299b39f647ca9961f30510f5292 $0 . p d f$

Critical Appraisal Skills Programme (CASP), (2017b). Systematic Review Checklist. . Retrieved from http://docs.wixstatic.com/ugd/dded87_7e983a320087439e94533f4697aa10 9c.pdf

Cingi, C., Yorgancioglu, A., Cingi, C. C., Oguzulgen, K., Muluk, N. B., Ulusoy, S., Orhon, N., Yumru, C., Gokdag, D., Karakaya, G., Celebi, S., Cobanoglu, H. B., Unlu, H., Aksoy, M. A. (2015). The "physician on call patient engagement trial" (POPET): measuring the impact of a mobile patient engagement application on health outcomes and quality of life in allergic rhinitis and asthma patients. International Forum of Allergy \& Rhinology, 5(6), 487-497. doi:10.1002/alr.21468

Dickson, R. L., Sumathipala, D., \& Reeves, J. (2016). Stop Stroke@ Acute Care Coordination Medical Application: A Brief Report on Postimplementation Performance at a Primary Stroke Center. Journal of Stroke and Cerebrovascular Diseases, 25(5), 1275-1279. doi:10.1016/j.jstrokecerebrovasdis.2015.12.001

Foo, E., McDonald, R., Savage, E., Floyd, R., Butler, A., Rumball-Smith, A., \& Connor, S. (2015). Mobile task management tool that improves workflow of an acute general surgical service. ANZ Journal of Surgery, 85(10), 760-765. doi:10.1111/ans.12988

Gernart, M., Tsianakas, A., Zeidler, C., Riepe, C., Osada, N., Pihan, D., \& Ständer, S. (2017). Itchapp@: An app-based eDiary for assessment of chronic pruritus in clinical trials. Acta Dermato-Venereologica, 97(5), 601-606. doi:10.2340/00015555-2602

Gunter, R., Fernandes-Taylor, S., Mahnke, A., Awoyinka, L., Schroeder, C., Wiseman, J., . . . Kent, K. C. (2016). Evaluating Patient Usability of an Image-Based Mobile Health Platform for Postoperative Wound Monitoring. Jmir Mhealth and Uhealth, 4(3). doi:10.2196/mhealth.6023

Hopia, H., Latvala, E., \& Liimatainen, K. (2016) Reviewing the methodology of an integrative review. Scandanavian Journal of Caring Science, 30(4), 662669.doi: $10.1111 /$ scs.12327 
Higgins, J. P. T., Altman, D. G., Gøtzsche, P. C., Jüni, P., Moher, D., Oxman, A. D., . . Sterne, J. A. C. (2011). The Cochrane Collaboration's tool for assessing risk of bias in randomised trials. BMJ, 343. doi:10.1136/bmj.d5928

Holmen, H., Wahl, A. K., Smastuen, M. C., \& Ribu, L. (2017). Tailored Communication Within Mobile Apps for Diabetes Self-Management: A Systematic Review. Journal of Medical Internet Research, 19(6). doi:10.2196/jmir.7045

Institute for Healthcare Improvement (IHI). (2018). Science of improvement. Retrieved from http://www.ihi.org/about/Pages/Scienceoflmprovement.aspx

Jakel, P., Kenney, J., Ludan, N., Miller, P. S., McNair, N., \& Matesic, E. (2016). Effects of the use of the Provider Resilience mobile application in reducing compassion fatigue in oncology nursing. Clinical Journal of Oncology Nursing, 20(6), 611-616. doi:10.1188/16.CJON.611-616

Khanna, V., Sambandam, S. N., Gul, A., \& Mounasamy, V. (2015). “WhatsApp"ening in orthopedic care: a concise report from a 300-bedded tertiary care teaching center. European Journal of Orthopaedic Surgery and Traumatology, 25(5), 821-826. doi:10.1007/s00590-015-1600-y

Kitsiou, S., Pare, G., Jaana, M., \& Gerber, B. (2017). Effectiveness of mHealth interventions for patients with diabetes: An overview of systematic reviews. PLOS ONE, 12(3). doi:10.1371/journal.pone.0173160

Lakshminarayana, R., Wang, D. L., Burn, D., Chaudhuri, K. R., Galtrey, C., Guzman, N. V., Hellmen, B., James, B., Pal, S., Stamford, J., Steiger, M., Stott, R. W., Teo, J., Barker, R. A., Wang, E., Bloem, B.R., van der Eijk, M., Rochester, L., Williams, A. (2017). Using a smartphone-based self-management platform to support medication adherence and clinical consultation in Parkinson's disease. Npj Parkinsons Disease, 3, 9. doi:10.1038/s41531-016-0003-z

Lee, Y., Shin, S. Y., Kim, J. Y., Kim, J. H., Seo, D. W., Joo, S., . . Bates, D. W. (2015). Evaluation of mobile health applications developed by a tertiary hospital as a tool for quality improvement breakthrough. Healthcare Informatics Research, 21(4), 299-306. doi:10.4258/hir.2015.21.4.299

Macpherson, C. F., Linder, L. A., Ameringer, S., Erickson, J., Stegenga, K., \& Woods, N. F. (2014). Feasibility and acceptability of an iPad application to explore symptom clusters in adolescents and young adults with cancer. Pediatric Blood \& Cancer, 61(11), 1996-2003. doi:10.1002/pbc.25152

McCance, T., Wilson, V \& Kornman, K. (2016). Paediatric International Nursing Study: using person-centred key performance indicators to benchmark children's services. Journal of Clinical Nursing, 25 2018-2027. doi:10.1111/jocn.13232

Patel, N., Siegler, J. E., Stromberg, N., Ravitz, N., \& Hanson, C. W. (2016). Perfect storm of inpatient communication needs and an innovative solution utilizing smartphones and secured messaging. Applied Clinical Informatics, 7(3), 777789. doi:10.4338/ACl-2015-11-RA-0151

Peiris, D., Praveen, D., Johnson, C., \& Mogulluru, K. (2014). Use of mHealth Systems and Tools for Non-Communicable Diseases in Low- and Middle-Income Countries: a Systematic Review. Journal of Cardiovascular Translational Research, 7(8), 677-691. doi:10.1007/s12265-014-9581-5

Semple, J. L., Sharpe, S., Murnaghan, M. L., Theodoropoulos, J., \& Metcalfe, K. A. (2015). Using a Mobile App for Monitoring Post-Operative Quality of 
Recovery of Patients at Home: A Feasibility Study. Jmir Mhealth and Uhealth, 3(1). doi:10.2196/mhealth.3929

Sundberg, K., Wengström, Y., Blomberg, K., Hälleberg-Nyman, M., Frank, C., \& Langius-Eklöf, A. (2017). Early detection and management of symptoms using an interactive smartphone application (Interaktor) during radiotherapy for prostate cancer. Supportive Care in Cancer, 25(7), 2195-2204. doi:10.1007/s00520-017-3625-8

Twichell, S. A., Rea, C. J., Melvin, P., Capraro, A. J., Mandel, J. C., Ferguson, M. A., Nigrin, D. J., Mandl, K. D., Graham, D., Zachariah, J. P. (2017). The effect of an electronic health record-based tool on abnormal pediatric blood pressure recognition. Congenital Heart Disease, 12(4), 484-490. doi:10.1111/chd.12469

Whittemore, R.,\& Knafl, K. (2005) The integrative review: updated methodology. Journal of Advanced Nursing, 52(5), 546-553. doi:10.1111/i.13652648.2005.03621.x

Wolf, A., Fors, A., Ulin, K., Thorn, J., Swedberg, K., \& Ekman, I. (2016). An eHealth diary and symptom-tracking tool combined with person-centered care for improving self-efficacy after a diagnosis of acute coronary syndrome: A substudy of a randomized controlled trial. Journal of Medical Internet Research, 18(2). doi:10.2196/jmir.4890

World Health Organization (WHO) Global Observatory for eHealth. (2011).mHealth: New horizons for health through mobile technologies: second global survey on eHealth. Retreived from http://www.who.int/iris/handle/10665/44607

World Health Organization (WHO). (2016). From Innovation to Implementation eHealth in the WHO European Region. Retrieved from http://www.euro.who.int/en/ehealth website: 


\section{Figure i) Literature search flow diagram}
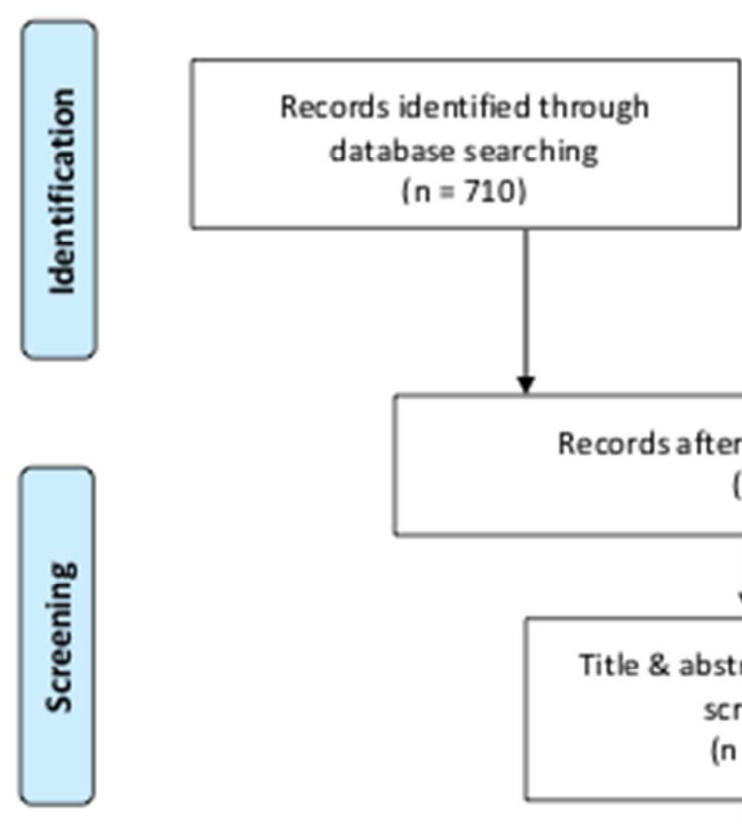

(

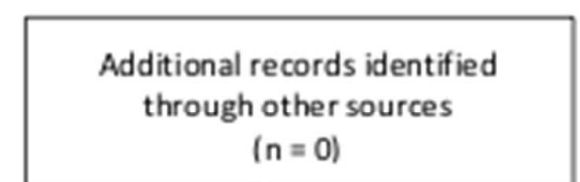

Studies included in qua lita tive synthesis $(n=19)$
Records excluded ( $n=563$ )

Full-text articles excluded based on criteria ( $\mathrm{n}=56$ )

23- Not relating to clinical context 12- Not relating to mHealth app use 12- Relating to app development 4- Apps not for information not data collection

2-Editorials

1-Conference paper

1- Research protocol

1- No full text available 
Table 1. Web of Science Search strategy

\begin{tabular}{|c|c|}
\hline \#1 & TOPIC apps OR app OR “mobile application” \\
\hline \#2 & TITLE apps OR app OR “mobile application" \\
\hline \#3 & TOPIC healthcare OR "healthcare" OR hospital OR nursing \\
\hline \#4 & TITLE healthcare OR "healthcare" OR hospital OR nursing \\
\hline \#5 & TOPIC "quality improvement" OR "quality*" OR "practice improvement" \\
\hline \#6 & ement" OR "quality*” OR "practice improvement" \\
\hline \#7 & \#1 OR \#2 \\
\hline \#8 & \#3 OR \#4 \\
\hline \#9 & \#5 OR \#6 \\
\hline \#10 & \#7 AND \#8 AND \#9 \\
\hline \#11 & Refine to ENGLISH + ARTICLE OR REVIEW \\
\hline$\# 12$ & Refine to EXCLUDE non-health/medicine \\
\hline
\end{tabular}


Table 2. Characteristics of included studies.

\begin{tabular}{|c|c|c|c|c|c|c|c|}
\hline Author \& Year & Country & Population & Study Aim & Study Design & App name \& function & $\begin{array}{c}\text { Data } \\
\text { Collected }\end{array}$ & $\begin{array}{l}\text { Results/Quality } \\
\text { Improvement }\end{array}$ \\
\hline $\begin{array}{l}\text { Armstrong et al., } \\
2017\end{array}$ & Canada & $\begin{array}{l}\text { Ambulatory adult } \\
\text { patients } \\
\text { undergoing } \\
\text { breast } \\
\text { reconstruction }\end{array}$ & $\begin{array}{l}\text { To determine whether } \\
\text { follow up-care delivered } \\
\text { via a mobile app can be } \\
\text { used to avert in-person } \\
\text { follow-up care visits } \\
\text { compared with } \\
\text { conventional, in person } \\
\text { follow-up care in the first } \\
30 \text { days post ambulatory } \\
\text { surgery }\end{array}$ & $\begin{array}{l}\text { Randomised } \\
\text { control trial } \\
\text { Sixty-five } \\
\text { participants }\end{array}$ & $\begin{array}{l}\text { QoC Health Inc Mobile } \\
\text { App Allows patients to: - } \\
\text { submit photographs, } \\
\text { answer a validated } \\
\text { quality of recovery } \\
\text { questionnaire and a } \\
\text { pain visual analogue } \\
\text { scale using a mobile } \\
\text { device for the first } 30 \\
\text { days after the operation } \\
\text { Surgeons can follow } \\
\text { patient reports on a web } \\
\text { portal }\end{array}$ & $\begin{array}{l}\text { Textual } \\
\text { Image }\end{array}$ & $\begin{array}{l}\text { Participants using the app } \\
\text { reported greater level of } \\
\text { convenience in follow up } \\
\text { care compared to in-person } \\
\text { group } \\
\text { minimal difference between } \\
\text { satisfaction scores between } \\
\text { app group vs in-person } \\
\text { group } \\
\text { neither satisfaction or } \\
\text { convenience scores were } \\
\text { statistically significant }\end{array}$ \\
\hline Cingi et al., 2015 & Turkey & $\begin{array}{l}\text { Patients with } \\
\text { allergic rhinitis } \\
\text { and asthma } \\
\text { (no age group } \\
\text { specified) }\end{array}$ & $\begin{array}{l}\text { Impact of mobile patient } \\
\text { engagement app on } \\
\text { health outcomes and } \\
\text { quality of life }\end{array}$ & $\begin{array}{l}\text { Randomized } \\
\text { control trial } \\
\text { Three hundred } \\
\text { and seventy-five } \\
\text { participants }\end{array}$ & $\begin{array}{l}\text { POPET (Physician On- } \\
\text { Call Patient } \\
\text { Engagement Trial) } \\
\text { Communication, health } \\
\text { management, } \\
\text { medication compliance }\end{array}$ & $\begin{array}{l}\text { Numerical } \\
\text { Textual }\end{array}$ & $\begin{array}{l}\text { Improved quality of life and } \\
\text { clinical outcomes. } \\
\text { Rhinitis group Clinical } \\
\text { improvement, improvement } \\
\text { in rhinitis quality of life, } \\
\text { activity (statistical } \\
\text { significance } p=0.05 \text { ) } \\
\text { Asthma group improved } \\
\text { number of well controlled } \\
\text { asthma score }\end{array}$ \\
\hline $\begin{array}{l}\text { Dickson, } \\
\text { Sumathipala \& } \\
\text { Reeves, } 2016\end{array}$ & $\begin{array}{l}\text { United } \\
\text { States of } \\
\text { America }\end{array}$ & $\begin{array}{l}\text { Patients with } \\
\text { Acute Ischaemic } \\
\text { Stroke (AIS) } \\
\text { (no age specified) }\end{array}$ & $\begin{array}{l}\text { Evaluate effect of app } \\
\text { on door-to-needle (DTN) } \\
\text { time in patients } \\
\text { presenting to } \\
\text { Emergency } \\
\text { Departments with AIS }\end{array}$ & $\begin{array}{l}\text { Retrospective } \\
\text { cohort study } \\
\text { Eighty-five } \\
\text { activations over } \\
\text { 18-month period }\end{array}$ & $\begin{array}{l}\text { Pulsara StopStroke } \\
\text { Medical app aimed at } \\
\text { enhancing rapid } \\
\text { assessment and care of } \\
\text { patients suffering from } \\
\text { AIS }\end{array}$ & Numerical & $\begin{array}{l}\text { App use resulted in } \\
\text { reduction in door-to-needle } \\
\text { time by } 46 \%(p=0.001)\end{array}$ \\
\hline
\end{tabular}




\begin{tabular}{|c|c|c|c|c|c|c|c|}
\hline Foo et al., 2015 & New Zealand & $\begin{array}{l}\text { Healthcare } \\
\text { clinicians } \\
\text { (consultants, } \\
\text { junior doctors \& } \\
\text { house officers) }\end{array}$ & $\begin{array}{l}\text { Assess impact of mobile } \\
\text { task management tool } \\
\text { on clinical workflow } \\
\text { within an acute general } \\
\text { surgical service }\end{array}$ & $\begin{array}{l}\text { Pilot study } \\
\text { Sixteen staff } \\
\text { members (where } \\
14 / 16 \text { completed } \\
\text { usability survey) }\end{array}$ & $\begin{array}{l}\text { Cortex - mobile iOS } \\
\text { task management } \\
\text { application } \\
\text { - provides the clinical } \\
\text { team with digitization of } \\
\text { the patient journey, } \\
\text { synchronous with } \\
\text { decision-making and } \\
\text { clinical task } \\
\text { performance }\end{array}$ & $\begin{array}{l}\text { Numerical } \\
\text { Graphical }\end{array}$ & $\begin{array}{l}\text { Faster decision making } \\
\text { reduced redundancy of work } \\
\text { improved team } \\
\text { communication } \\
\text { capture of data re: patient } \\
\text { journey and workflow which } \\
\text { was not previously available }\end{array}$ \\
\hline $\begin{array}{l}\text { Gernart et al., } \\
2017\end{array}$ & Germany & $\begin{array}{l}\text { Adult patients } \\
\text { with chronic } \\
\text { pruritus }\end{array}$ & $\begin{array}{l}\text { To validate ItchApp as a } \\
\text { novel instrument }\end{array}$ & $\begin{array}{l}\text { Validation study } \\
\text { and Randomised, } \\
\text { double-blind } \\
\text { placebo- } \\
\text { controlled trial } \\
\text { using the app } \\
\text { Forty participants }\end{array}$ & $\begin{array}{l}\text { ItchApp - E-diary for } \\
\text { use in clinical trials to } \\
\text { generate increased } \\
\text { reliability of prospective } \\
\text { data } \\
\text { Obtains data on: itch } \\
\text { intensity questionnaires, } \\
\text { quality of life }\end{array}$ & $\begin{array}{l}\text { Numerical and } \\
\text { textual }\end{array}$ & $\begin{array}{l}\text {-94\% level of patient } \\
\text { compliance } \\
\text {-data from app easily } \\
\text { managed and analysed } \\
\text {-simplified data collection } \\
\text { process }\end{array}$ \\
\hline $\begin{array}{l}\text { Gunter et al., } \\
2016\end{array}$ & $\begin{array}{l}\text { United } \\
\text { States of } \\
\text { America }\end{array}$ & $\begin{array}{l}\text { Adult patients } \\
>18 \text { years in the } \\
\text { vascular or } \\
\text { general surgery } \\
\text { service of a large } \\
\text { tertiary hospital }\end{array}$ & $\begin{array}{l}\text { 1) develop a novel } \\
\text { image-based } \\
\text { smartphone app for post } \\
\text { discharge surgical } \\
\text { wound monitoring } \\
\text { 2) rigorously user test it } \\
\text { with a representative } \\
\text { population of vascular } \\
\text { and general surgery } \\
\text { patients }\end{array}$ & $\begin{array}{l}\text { Descriptive study } \\
\text { Nine participants }\end{array}$ & $\begin{array}{l}\text { Woundcheck an iOS } \\
\text { app that enables } \\
\text { patients to capture } \\
\text { digital images of } \\
\text { surgical wounds and } \\
\text { sends them to their } \\
\text { provider from home } \\
\text { along with brief updates } \\
\text { of post op recovery } \\
\text { Includes } 2 \text { phases } \\
\text { 1- image taking phase } \\
2 \text { - brief survey with } 6 \\
\text { yes or no questions re: } \\
\text { recovery }\end{array}$ & $\begin{array}{l}\text { Imaged } \\
\text { Textual }\end{array}$ & $\begin{array}{l}\text { Above average overall } \\
\text { usability score } 83.3 \\
\text { At the time of publication } \\
\text { first app to add } \\
\text { asynchronous visual } \\
\text { component to outpatient } \\
\text { monitoring apps. } \\
\text { Testing allowed for change } \\
\text { to be made to the app and } \\
\text { identify gaps in education } \\
\text { support for patients using } \\
\text { app. }\end{array}$ \\
\hline $\begin{array}{l}\text { Holmen et al., } \\
2017\end{array}$ & $\begin{array}{l}\text { Studies from } \\
\text { Japan }\end{array}$ & $\begin{array}{l}\text { Patients }>16 \\
\text { years with }\end{array}$ & $\begin{array}{l}\text { Systematically review } \\
\text { studies that aimed to }\end{array}$ & $\begin{array}{l}\text { Systematic } \\
\text { literature review }\end{array}$ & $\begin{array}{l}\text { Majority of apps } \\
\text { focusing on }\end{array}$ & $\begin{array}{l}\text { Numerical } \\
\text { Textual }\end{array}$ & $\begin{array}{l}\text { Unclear methodological } \\
\text { quality of studies, }\end{array}$ \\
\hline
\end{tabular}


\begin{tabular}{|l|l|l|} 
China & diabetes (type 1 & evaluate integrated \\
\hline
\end{tabular}

\begin{tabular}{l|l|l} 
Korea & and type 2) & communication within
\end{tabular}

Democratic

Republic of

Congo

Canada and

1 multicentre

study in Italy,

Spain and

Czech

Republic

\& Mounasamy

\section{mobile apps for tailored}

feedback between

patients with diabetes

and health care

personnel in terms of

study characteristics,

functions, study

outcomes, effects and methodological quality

\section{United \\ States of}

Adult oncology

nurses

Ex

Examine if the use of

the app will improve oncology nurses professional quality of life

\begin{tabular}{|c|c|c|c|}
\hline & $\begin{array}{l}\text { communication e.g. } \\
\text { SMS interaction, } \\
\text { reminders, texting of } \\
\text { blood glucose levels, } \\
\text { feedback from health } \\
\text { care professional and } \\
\text { therapeutic advice. } \\
\text { Small number of apps } \\
\text { transmitting blood } \\
\text { glucose level and } \\
\text { dietary intake. } \\
\text { Others relating to self- } \\
\text { management \& } \\
\text { education, }\end{array}$ & & $\begin{array}{l}\text { implications for need for } \\
\text { more controlled trials of } \\
\text { higher methodological } \\
\text { quality } \\
\text { Outcome measures of app } \\
\text { related to disease } \\
\text { management but did not } \\
\text { mention outcomes relating } \\
\text { to quality improvement } \\
1 / 6 \text { measured therapy } \\
\text { satisfaction }\end{array}$ \\
\hline $\begin{array}{l}\text { Prospective } \\
\text { quasi- } \\
\text { experimental pilot } \\
\text { study } \\
25 \text { participants }\end{array}$ & $\begin{array}{l}\text { PRMA (Provider } \\
\text { Resilience Mobile } \\
\text { Application) tool to } \\
\text { increase provider } \\
\text { resilience. It includes } \\
\text { psychoeducation, } \\
\text { methods to evaluate } \\
\text { level of burnout, } \\
\text { compassion fatigue, } \\
\text { compassion satisfaction } \\
\text { and secondary trauma } \\
\text { stress using a visual } \\
\text { analogue scale, } \\
\text { questionnaire, and r\&r } \\
\text { clock to remind } \\
\text { participants time since } \\
\text { the user took a day off }\end{array}$ & $\begin{array}{l}\text { Numerical } \\
\text { Textual } \\
\text { Graphic }\end{array}$ & $\begin{array}{l}\text { No change seen in the pre- } \\
\text { and post-test scores of the } \\
\text { intervention group, control } \\
\text { group or sample as a whole }\end{array}$ \\
\hline $\begin{array}{l}\text { Retrospective } \\
\text { study } \\
\text { Eight residents }\end{array}$ & $\begin{array}{l}\text { WhatsApp - cross } \\
\text { platform mobile } \\
\text { messaging app allowing } \\
\text { the exchange of }\end{array}$ & $\begin{array}{l}\text { Textual } \\
\text { images } \\
\text { numerical }\end{array}$ & $\begin{array}{l}\text { High scores indicating } \\
\text { improved awareness of } \\
\text { patient information } \\
\text { statistically significant }(p=\end{array}$ \\
\hline
\end{tabular}



2017 communication tool on 1) awareness of patient related information

2) efficiency of handover process

3) duration of traditional morning handovers among orthopaedic residents

Patients with type Purpose of the overview

United

States of

1 and type 2

is to critically appraise

America

United

Kingdom

China

Canada

Iran

akshminarayana

et al., 2017

\section{United}

Kingdom and consolidate

evidence from multiple

systematic reviews on

the effectiveness of

mHealth interventions

for patients with

diabetes to inform policy makers, practitioners

and researchers

\section{Patients with \\ Parkinson's}

Disease

68 patients in

PTA group and

90 in TAU group

\begin{tabular}{|c|c|c|c|}
\hline $\begin{array}{l}\text { participated } \\
\text { Total } 50 \\
\text { admissions } \\
\text { reviewed } \\
\text { ( } 25 \text { pre- } \\
\text { WhatsApp } \\
25 \text { post } \\
\text { WhatsApp) }\end{array}$ & $\begin{array}{l}\text { messages and media } \\
\text { over the internet }\end{array}$ & & $\begin{array}{l}0.019) \text {. } \\
\text { All residents found } \\
\text { WhatsApp helpful in } \\
\text { improving the efficiency of } \\
\text { handovers and standard of } \\
\text { patient care. } \\
\text { Statistically significant } \\
\text { reduction in the time of } \\
\text { written handovers in the } \\
\text { morning from } 25 \text { minutes to } \\
14 \text { minutes }(p=0.003)\end{array}$ \\
\hline $\begin{array}{l}\text { Systematic } \\
\text { review }\end{array}$ & $\begin{array}{l}\text { Majority of apps } \\
\text { focusing on } \\
\text { communication e.g. } \\
\text { SMS interaction, } \\
\text { reminders, texting of } \\
\text { blood glucose levels, } \\
\text { feedback from health } \\
\text { care professional and } \\
\text { therapeutic advice. } \\
\text { Small number of apps } \\
\text { transmitting blood } \\
\text { glucose level and } \\
\text { dietary intake } \\
\text { Others relating to self- } \\
\text { management \& } \\
\text { education, }\end{array}$ & $\begin{array}{l}\text { Textual } \\
\text { Numerical }\end{array}$ & $\begin{array}{l}\text { On average mhealth } \\
\text { interventions reviewed } \\
\text { improved glycaemic control } \\
\text { compared to standard care } \\
\text { of other non mhealth } \\
\text { approaches as much as } \\
0.8 \% \text { for patients with type } 2 \\
\text { diabetes and } 0.3 \% \text { for } \\
\text { patients with type } 1 \\
\text { diabetes. } \\
\text { Large variability in quality of } \\
\text { studies reviewed }\end{array}$ \\
\hline $\begin{array}{l}\text { Randomized } \\
\text { control trial } \\
\text { One hundred and } \\
\text { fifty-eight } \\
\text { participants }\end{array}$ & $\begin{array}{l}\text { Parkinson's tracker app } \\
\text {-Sliding petal interface } \\
\text { to track } 10 \text { self- } \\
\text { monitoring measures on } \\
\text { a 5-point scale (sleep, } \\
\text { exercise, mood, energy, } \\
\text { movement suppleness) } \\
\text {-Reminder system for }\end{array}$ & $\begin{array}{l}\text { Numerical } \\
\text { Textual }\end{array}$ & $\begin{array}{l}\text { Statistically significant result } \\
\text { indicating use of app to } \\
\text { produce quality } \\
\text { improvement for patients } \\
\text { with Parkinson's disease } \\
\text { over 16-week period. } \\
\text {-Improved patients' } \\
\text { perception of quality of }\end{array}$ \\
\hline
\end{tabular}


medication adherence. Secondary objectives were to investigate whether patients who receive the PTA and those who receive TAU differ in terms of quality of life, quality of clinical consultation and symptom control clinicians

\begin{tabular}{|c|c|c|c|}
\hline & $\begin{array}{l}\text { patients to set up for } \\
\text { alerts to track } \\
\text { medication } \\
\text {-Option to generated a } \\
\text { report of data entered } \\
\text { by the patient over the } \\
\text { trial period as an aid at } \\
\text { their } 16 \text { week follow up } \\
\text { appointment } \\
\text {-Games to track } \\
\text { physical responsiveness } \\
\text {-Information about } \\
\text { Parkinson's disease }\end{array}$ & & $\begin{array}{l}\text { consultation }(p=0.0110) \\
\text {-Improved medication } \\
\text { adherence compared to } \\
\text { treatment as usual ( } p= \\
0.0304)\end{array}$ \\
\hline $\begin{array}{l}\text { Evaluation/ } \\
\text { Systematic } \\
\text { Review of twenty } \\
\text { three studies in } \\
\text { Korea . } \\
\text { Apps evaluated } \\
\text { re: } 6 \text { aims for } \\
\text { quality } \\
\text { improvement } \\
\text { suggested by US } \\
\text { Institute of } \\
\text { Medicine (patient } \\
\text { centredness, } \\
\text { effectiveness, } \\
\text { patient safety, } \\
\text { timeliness, } \\
\text { efficiency, equity) }\end{array}$ & $\begin{array}{l}23 \text { different apps } \\
\text { PATIENTS } \\
\text {-my medications } \\
\text {-my chart in my hand } \\
\text {-pharm consult } \\
\text {-wild plants in Korea } \\
\text {-pediatric cancer diary } \\
\text {-injini } \\
\text {-quality of life } \\
\text {-my cancer diary } \\
\text {-pediatric cancer } \\
\text { information } \\
\text {-pit-a-pat } \\
\text { BOTH } \\
\text {-emergency in ordinary } \\
\text { life } \\
\text { HEALTHCARE } \\
\text { PROVIDERS } \\
\text {-ASAN phonebook } \\
\text {-CPCR drugs } \\
\text {-toxicology } \\
\text {-mAMIS }\end{array}$ & $\begin{array}{l}\text { Textual } \\
\text { numerical } \\
\text { Several apps } \\
\text { provided } \\
\text { information } \\
\text { rather than } \\
\text { collect data } \\
8 / 23 \text { apps }\end{array}$ & $\begin{array}{l}\text { Apps designed between } \\
2010-2014 \\
\text { - Only } 2 \text { apps met all } 6 \text { aims } \\
\text { for quality improvement } \\
\text {-Most of the apps designed } \\
\text { for patients provide health } \\
\text { information or patient } \\
\text { medical information ( } 7 / 10 \\
\text { apps) } \\
\text {-1 app for patients collected } \\
\text { survey data } \\
\text {-4/23 apps were personal } \\
\text { health record } \\
\text {-3/13 healthcare provider } \\
\text { apps focussed on } \\
\text { communication }\end{array}$ \\
\hline
\end{tabular}




\section{Macpherson et}

\section{United}

States of

72 adolescents

and young adults
$13-29$ years of

age with cancer

at 5 institutions

across the USA

\section{Aim of the study was to} evaluate the feasibility and acceptability of a

computer based

symptom cluster heuristics tool designed

to explore symptom clusters experienced by adolescents and young adults with cancer

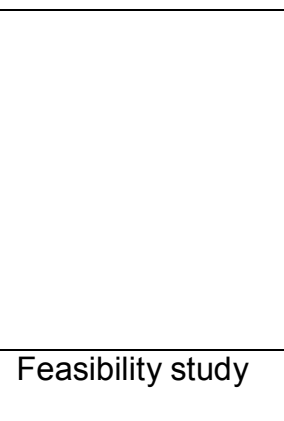

-ASAN-in

emergency in ordinary life

-blood culture app

- mobile ASANnet

-ASAN talk

-Ora-Quick app

-AMC ARC

-patient transportation

Hea

\section{Healthcare}

Seventy-two

Computerized symptom

capture tool (C-SCAT)

participants

Features 30 symptoms

commonly experienced

by adolescents and

young adults with

cancer,

combines graphical

images and free text

responses in an

innovative heuristics

approach to gain the

perspectives of AYA's

on their symptoms and

symptom clusters

Allows participants to

drag and drop the

symptoms experienced

in the last 24 hours

\section{To determine if a}

teams, doctors

commercially available

smartphone based

Pre-post
evaluation study

Cureatr- Health

Insurance Portability

and Accountability Act Text messages

\section{All 72 participants}

Textual

Graphical

completed the C-SCAT with

$74 \%$ of participants reported

that the final image was an

accurate or very accurate

representation of their

symptom experience

C-SCAT demonstrated feasibility and acceptability app has potential to empower adolescents and

young adults to 1 )

communicate symptom experience and partner with

providers in their care

2) improve symptom

management and

ameliorate distress

3) translate to use with other highly symptomatic

\section{populations}

Different number of

respondents in pre-and post

evaluation study and

inability to link responses 


\section{Adults (patients} and volunteers) with non-

communicable diseases (cardiovascular disease, diabetes, cancer, application has the potential to allow providers to communicate efficiently and effectively as a care team. general medical units

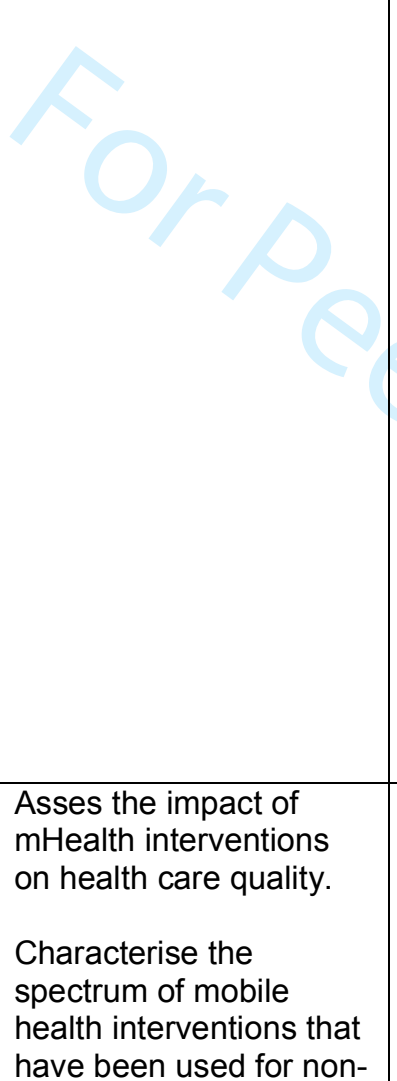

\begin{tabular}{|c|c|c|c|}
\hline $\begin{array}{l}\text { were analysed to } \\
\text { evaluate } \\
\text { utilization, pattern } \\
\text { and adoption of } \\
\text { the } \\
\text { communication } \\
\text { solution } \\
1021 \text { providers } \\
\text { involved sent } \\
708,456 \\
\text { messages } \\
\text { One hundred and } \\
\text { thirty-six nurses } \\
\text { and ninety-three } \\
\text { physicians } \\
\text { completed pre- } \\
\text { survey } \\
\text { One hundred and } \\
\text { twenty-seven } \\
\text { nurses and } \\
\text { eighty-three } \\
\text { physicians } \\
\text { completed post } \\
\text { survey }\end{array}$ & $\begin{array}{l}\text { messaging application } \\
\text { Used for the } \\
\text { transmission of } \\
\text { encrypted text } \\
\text { messages via hospital } \\
\text { wireless network }\end{array}$ & & $\begin{array}{l}\text { from first and second survey } \\
\text { made interpretation of } \\
\text { results difficult. } \\
\text { Large number of group } \\
\text { messages } 1 / 6 \text { messages } \\
\text { indicating that use of the } \\
\text { app facilitates virtual team } \\
\text { conversations } \\
\text { Nurses and residents } \\
\text { reported that texting on } \\
\text { smart devices was more } \\
\text { efficient and less disruptive } \\
\text { than using phone calls or } \\
\text { pagers } \\
\text { Further research required to } \\
\text { determine impact on patient } \\
\text { outcomes and confirm } \\
\text { effectiveness and safety of } \\
\text { messaging solution }\end{array}$ \\
\hline $\begin{array}{l}\text { Systematic } \\
\text { Literature Review }\end{array}$ & $\begin{array}{l}48 \text { studies across Brazil, } \\
\text { Turkey, China, } \\
\text { Honduras, India, } \\
\text { Malaysia, Cameroon, } \\
\text { Thailand, Iran, } \\
\text { Argentina \& Mexico. } \\
\text { Apps focussed on: }\end{array}$ & $\begin{array}{l}\text { Textual } \\
\text { Numerical }\end{array}$ & $\begin{array}{l}\text { mHealth for non- } \\
\text { communicable diseases is } \\
\text { under-explored, however } \\
\text { several study protocols } \\
\text { indicating future growth in } \\
\text { this area. } \\
\text { Despite mHealth having a }\end{array}$ \\
\hline
\end{tabular}




\section{Ambulatory care}

patients

undergoing

breast

reconstruction or

orthopaedic

arthroscopic

anterior cruciate

ligament repair

\begin{tabular}{|c|c|c|c|c|}
\hline $\begin{array}{l}\text { communicable disease } \\
\text { management and } \\
\text { prevention in low and } \\
\text { middle- income } \\
\text { countries }\end{array}$ & & $\begin{array}{l}\text {-Sensors and point of } \\
\text { care diagnostics } \\
\text {-communication } \\
\text {-Decision support } \\
\text {-Client education } \\
\text {-Telecare intervention } \\
\text {-Disease management } \\
\text { - SMS reminder system } \\
\text {-interactive voice } \\
\text { system } \\
\text {-disease monitoring } \\
\text {-electronic health record } \\
\text {-medication adherence } \\
\text {-data collection }\end{array}$ & & $\begin{array}{l}\text { wide variety of applications, } \\
\text { studies so far are dominated } \\
\text { by behaviour change } \\
\text { interventions through use of } \\
\text { text messaging systems. } \\
\text { Few studies have applied } \\
\text { mHealth tools as a means } \\
\text { of strengthening health } \\
\text { systems/quality } \\
\text { improvement. } \\
\text { No studies looked at equity } \\
\text { or safety issues }\end{array}$ \\
\hline $\begin{array}{l}\text { To assess the feasibility } \\
\text { of using a mobile app } \\
\text { for the monitoring or } \\
\text { post-operative quality of }\end{array}$ & $\begin{array}{l}\text { Prospective } \\
\text { cohort study (pilot } \\
\text { study) }\end{array}$ & $\begin{array}{l}\text { App name not outlined. } \\
\text {-Using photographic } \\
\text { data of wound uploaded } \\
\text { daily }\end{array}$ & Imaged & $\begin{array}{l}\text { Effective Mobile app } \\
\text { monitoring is feasible and } \\
\text { acceptable to both patients } \\
\text { and surgeons }\end{array}$ \\
\hline
\end{tabular}

post-operative quality of

covery at home

following surgery in an

ambulatory setting

Sixty-five surgical participants

(Thirty-three

breast

reconstruction

and thirty-two

orthopaedic

surgery) -visual analogue scale

for pain and likert

questions from the

quality of recovery

questionnaire (QoR-9)

App would alert surgeon

if 'flag' value identified

from patient data input

\& would also place the

patient on top of the

surgeons list and

highlight them as red on

surgeons' dashboard

the surgeon could then

call the patient and

enquire re: the high

score, app updated
Patient satisfaction very high 3.9/4 satisfaction score

2 potential post op complications identified prior to scheduled follow up resulting in better patient outcome due to faster time of identification.

Cost and time effective benefit also highlighted by surgeons. 


\begin{tabular}{|c|c|c|c|c|c|c|c|}
\hline & & & & & every 5 mins & & \\
\hline $\begin{array}{l}\text { Sundberg et al., } \\
2017\end{array}$ & Sweden & $\begin{array}{l}\text { Male patients } \\
\text { mean age } 69 \\
\text { years with } \\
\text { prostate cancer }\end{array}$ & $\begin{array}{l}\text { Evaluate the effect on } \\
\text { symptom burden and } \\
\text { quality of life when using } \\
\text { the application for real- } \\
\text { time symptom } \\
\text { assessment and } \\
\text { management during } \\
\text { radiotherapy for } \\
\text { localised prostate } \\
\text { cancer }\end{array}$ & $\begin{array}{l}\text { Non-randomized } \\
\text { control trial } \\
\text { One hundred and } \\
\text { thirty participants } \\
\text { Sixty-four } \\
\text { participants in } \\
\text { control group } \\
\text { Sixty-six } \\
\text { participants in } \\
\text { intervention } \\
\text { group }\end{array}$ & $\begin{array}{l}\text { Interaktor } \\
\text { An app for smartphones } \\
\text { and tablets for early } \\
\text { detection, reporting and } \\
\text { management of } \\
\text { symptoms and concerns } \\
\text { during treatment for } \\
\text { prostate cancer. Allows } \\
\text { real time communication } \\
\text { and rapid management } \\
\text { of symptoms when } \\
\text { detected early }\end{array}$ & $\begin{array}{l}\text { Textual and } \\
\text { numerical }\end{array}$ & $\begin{array}{l}\text { Reporting symptoms via the } \\
\text { application had positive } \\
\text { effect on symptom burden } \\
\text { and quality of life } \\
\text { Statistically significant } \\
\text { results for intervention } \\
\text { group in emotional } \\
\text { functioning } \\
\text { Control group also had } \\
\text { statistically significant lower } \\
\text { levels of quality of life }\end{array}$ \\
\hline $\begin{array}{l}\text { Twichell et al., } \\
2017\end{array}$ & $\begin{array}{l}\text { United } \\
\text { States of } \\
\text { America }\end{array}$ & $\begin{array}{l}\text { Paediatric } \\
\text { patients } 3-18 \\
\text { years of age } \\
\text { with one BP } \\
\text { above the } 90^{\text {th }} \\
\text { age-sex-height } \\
\text { referenced } \\
\text { percentile }\end{array}$ & $\begin{array}{l}\text { Examine change in } \\
\text { abnormal blood } \\
\text { pressure recognition } \\
\text { before vs. after the } \\
\text { introduction of an } \\
\text { electronic health record } \\
\text { app designed to } \\
\text { calculate BP percentiles } \\
\text { with a training lecture }\end{array}$ & $\begin{array}{l}\text { Retrospective } \\
\text { cohort study } \\
78,768 \text { clinical } \\
\text { encounters } \\
\text { reviewed. } \\
\text { Three thousand } \\
\text { five hundred and } \\
\text { twenty-one had } \\
\text { abnormal BP's } \\
\text { pre-app use } \\
\text { Three thousand, } \\
\text { three hundred } \\
\text { and fifty-eight had } \\
\text { abnormal BP's } \\
\text { post app use }\end{array}$ & $\begin{array}{l}\text { Substitutable Medical } \\
\text { Applications \& Reusable } \\
\text { Technology (SMART) } \\
\text { BP Centiles App } \\
\text { Free, substitutable, } \\
\text { open-source, open } \\
\text { access BP calculator } \\
\text { and longitudinal tracking } \\
\text { tool capable of running } \\
\text { within any Electronic } \\
\text { Health Record that } \\
\text { supports the SMART } \\
\text { Health IT Platform. } \\
\text { The app displays the BP } \\
\text { percentile with an } \\
\text { ambulatory blood } \\
\text { pressure measurement, } \\
\text { as well as historic blood } \\
\text { pressure percentiles } \\
\text { allowing providers to } \\
\text { determine if an elevated }\end{array}$ & $\begin{array}{l}\text { Numerical } \\
\text { Graphical }\end{array}$ & $\begin{array}{l}\text { As app use was voluntary } \\
\text { and not mandated or } \\
\text { included in workflow, it was } \\
\text { only used in } 13 \% \text { of clinical } \\
\text { encounters when the BP } \\
\text { was elevated, = } 5 \% \text { use in } \\
\text { overall clinical encounters } \\
=\text { small sample. } \\
\text { Despite small sample size } \\
\text { app use was associated } \\
\text { with significantly higher } \\
\text { recognition of abnormal BP } \\
4.9 \% \text { pre-app and } 7.1 \% \\
\text { post app (p=0.0001) } \\
\text { Data generated by app } \\
\text { allowed medical staff to } \\
\text { track trends for patient and } \\
\text { not only improve recognition } \\
\text { of elevated BP, but observe }\end{array}$ \\
\hline
\end{tabular}




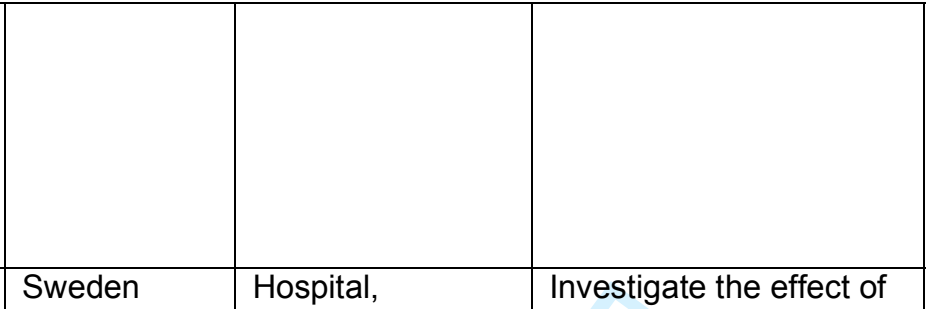

outpatients'

clinics and

primary care

patients < 75yrs,

English speaking

eHealth diary and

symptom tracking tool

combined with a person-

centred care

intervention in patients

hospitalised for an acute

coronary syndrome event

Sub study of a
randomized
control trial
Person centred
care after Acute
Coronary
Syndrome(PACS)
I Investigating the
effects of person
centred care in
patients
hospitalized with
acute coronary
syndrome

One hundred and

ninety-nine

participants

$(n=94$ in

intervention

group and $n=105$

in control group)

$\mathrm{Pt}$ had option to

use the webpage

or the mobile app

or both
BP represented an

isolated event or if the

patient has had multiple

elevated BP. It doesn't

provide further

recommendations re: $p t$.

management

App consisted of 3

modules:

1) self-rated fatigue

scale

2) symptom trend graph

3) build in

accelerometer within the

phone to provide a daily

average of the patients'

physical activity level

\section{Webpage had 5}

modules

1) self-rated symptoms

of fatigue

2) symptom trend graph

3) diary function for free

text entries to capture

every day experience

4) chat function with

other patients and

registered nurses within the study

5) personal links to

relevant webpages and

ability to upload

documents 


\begin{tabular}{|l|l|l|} 
Used the General & & \\
Self Efficacy & & \\
Scale (GSES) to & & \\
evaluate patient- & & \\
reported scores & & \\
at baseline, 4 & & \\
weeks, 8 weeks & & \\
and 6 months & & \\
\hline
\end{tabular}




\begin{tabular}{|c|c|c|c|}
\hline Communication & Illness management & Clinical management & Education/information \\
\hline $\begin{array}{l}\text { Messaging } \\
\text { (Cingi et al., 2015; Holmen et } \\
\text { al., 2017; Khanna et al., 2015; } \\
\text { Kitsiou et al., 2017; Lee et al., } \\
\text { 2015; Patel et al., 2016; Peiris } \\
\text { et al., 2014; Sundberg et al., } \\
\text { 2017) }\end{array}$ & $\begin{array}{l}\text { Medication compliance } \\
\text { (Lakshminarayana et al., } \\
\text { 2017; Peiris et al., 2014) }\end{array}$ & $\begin{array}{l}\text { Patient assessment } \\
\text { (Dickson et al., 2016) }\end{array}$ & $\begin{array}{l}\text { Disease information } \\
\text { (Lakshminarayana et al., 2017; Lee } \\
\text { et al., 2015; Peiris et al., 2014) }\end{array}$ \\
\hline $\begin{array}{l}\text { Image exchange } \\
\text { (Armstrong et al., 2017; } \\
\text { Gunter et al., 2016) }\end{array}$ & $\begin{array}{l}\text { Symptom tracking } \\
\text { (Holmen et al., 2017; } \\
\text { Kitsiou et al., 2017; Wolf } \\
\text { et al., 2016) }\end{array}$ & $\begin{array}{l}\text { Decision making } \\
\text { (Dickson et al., 2016) (Foo } \\
\text { et al., 2015; Peiris et al., } \\
\text { 2014) }\end{array}$ & $\begin{array}{l}\text { Treatment information } \\
\text { (Holmen et al., 2017; Jakel et al., } \\
\text { 2016; Lee et al., 2015) }\end{array}$ \\
\hline $\begin{array}{l}\text { Discussion } \\
\text { (Khanna et al., 2015) }\end{array}$ & $\begin{array}{l}\text { Diet and activity } \\
\text { (Kitsiou et al., 2017) } \\
\text { (Wolf et al., 2016) }\end{array}$ & $\begin{array}{l}\text { Symptom recognition } \\
\text { (Christiansen, Fjell, \& } \\
\text { Sundberg, 2017; Sundberg } \\
\text { et al., 2017; Twichell et al., } \\
\text { 2017) }\end{array}$ & $\begin{array}{l}\text { Illness management (Holmen et al., } \\
\text { 2017; Kitsiou et al., 2017; Peiris et } \\
\text { al., 2014) }\end{array}$ \\
\hline $\begin{array}{l}\text { Real-time feedback/advice } \\
\text { (Holmen et al., 2017) (Kitsiou } \\
\text { et al., 2017; Semple et al., } \\
\text { 2015; Sundberg et al., 2017) }\end{array}$ & $\begin{array}{l}\text { Post op recovery } \\
\text { (Armstrong et al., 2017; } \\
\text { Gunter et al., 2016; } \\
\text { Semple et al., 2015; } \\
\text { Sundberg et al., 2017) }\end{array}$ & $\begin{array}{l}\text { Diagnosis } \\
\text { (Twichell et al., 2017) }\end{array}$ & $\begin{array}{l}\text { Data collection } \\
\text { (Peiris et al., 2014) }\end{array}$ \\
\hline $\begin{array}{l}\text { Diary function } \\
\text { (Cingi et al., 2015) (Gernart et } \\
\text { al., 2017; Lee et al., 2015; } \\
\text { Wolf et al., 2016) }\end{array}$ & $\begin{array}{l}\text { Symptom burden } \\
\text { (Macpherson et al., } \\
\text { 2014; Sundberg et al., } \\
\text { 2017) }\end{array}$ & $\begin{array}{l}\text { Electronic health record } \\
\text { (Lee et al., 2015; Peiris et } \\
\text { al., 2014) }\end{array}$ & \\
\hline \multirow[t]{5}{*}{$\begin{array}{l}\text { Electronic health record } \\
\text { (Lee et al., 2015; Peiris et al., } \\
\text { 2014) }\end{array}$} & $\begin{array}{l}\text { Quality of life } \\
\text { (Cingi et al., 2015; } \\
\text { Gernart et al., 2017; Jakel } \\
\text { et al., 2016; Lee et al., } \\
\text { 2015; Sundberg et al., } \\
\text { 2017) }\end{array}$ & $\begin{array}{l}\text { Handover } \\
\text { (Khanna et al., 2015) }\end{array}$ & \\
\hline & $\begin{array}{l}\text { Self-monitoring (Jakel et } \\
\text { al., 2016; Kitsiou et al., } \\
\text { 2017; Lakshminarayana } \\
\text { et al., 2017; Peiris et al., } \\
\text { 2014; Wolf et al., 2016) }\end{array}$ & $\begin{array}{l}\text { Digitisation of patient } \\
\text { journey } \\
\text { (Foo et al., 2015) }\end{array}$ & \\
\hline & $\begin{array}{l}\text { Reminders (Holmen et } \\
\text { al., 2017; Jakel et al., } \\
\text { 2016; Kitsiou et al., 2017; } \\
\text { Lakshminarayana et al., } \\
\text { 2017; Peiris et al., 2014) }\end{array}$ & $\begin{array}{l}\text { Task performance } \\
\text { (Foo et al., 2015) }\end{array}$ & \\
\hline & $\begin{array}{l}\text { Pain assessment } \\
\text { (Semple et al., 2015) }\end{array}$ & $\begin{array}{l}\text { Follow up (Armstrong et } \\
\text { al., 2017; , Gunter et al., } \\
\text { 2016; Semple et al., 2015) }\end{array}$ & \\
\hline & $\begin{array}{l}\text { Diary function } \\
\text { (Gernart et al., 2017) } \\
\text { (Wolf et al., 2016) }\end{array}$ & & \\
\hline
\end{tabular}

Note: The reference in Table 3 are of the 19 studies included in this review 